\title{
Ethiopian Public Universities Leadership Behavior and Instructor's Job Satisfaction: Evidence From Arba Minch University
}

\author{
Zelalem Zekarias (PhD Candidate@AAU) \\ Department of Educational Planning and Management, PhD Program in Educational Policy and Leadership \\ Addis Ababa University
}

\begin{abstract}
The present study examines the link between leadership behavior and instructor's job satisfaction in four purposefully selected colleges and schools of Arba Minch University (AMU). The study participants were 167 randomly selected instructors of sampled colleges and schools. Of these, 149 were male instructors and the remaining18 were female ones. The data for the study were gathered via adapted questionnaire. The study employed quantitative correlational research design to examine the relationship between leadership behavior and instructor's job satisfaction. A Pearson's correlation coefficient (r) value was used to determine the correlation between the independent variable (leadership behavior) and the dependent variable (instructor's job satisfaction) and simple linear regression was employed to predict their relationship. The findings revealed that leadership behavior has statistically significant, positive and strong correlation with instructor's job satisfaction $(\mathrm{r}=.761$, $\mathrm{p}<.049$ two-tailed). The study further indicated that the value of $\mathrm{R}^{2}(.580)$ indicates $58 \%$ of the job satisfaction is explained by leadership behavior. From these findings, it was concluded that there is a positive link between leadership behavior and instructor's job satisfaction. Therefore, it was recommended that through both formal and informal trainings, the university leaders should aware how their leadership behavior is correlated with instructor's job satisfaction and then they should adopt and practice different dimensions of leadership behavior to improve instructor's job satisfaction.
\end{abstract}

Keywords: Leadership; Leadership behavior; Teacher; Instructor's Job satisfaction; Performance

DOI: $10.7176 / \mathrm{JEP} / 11-1-06$

Publication date: January $31^{\text {st }} 2020$

\section{INTRODUCTION}

\subsection{Background of the Study}

Leadership is considered as one of the key ingredients to the success of any organization (Jabbar \& Hussein, 2017). In the educational institutions, it is crucial to attain educational goals and objectives (Ali \& Dahie, 2015). Since instructional leaders are leading and working together with the key elements of education system like teachers and other stakeholders, they play an irreplaceable role in teachers' job satisfaction (Abbas \& Asghar, 2010).

Job satisfaction is very important to improve organizational performance. As studied by Bakotić (2016) highly satisfied employees perform better results than dissatisfied employees. In the higher education institutions (HEIs), instructor's job satisfaction is associated with various organizational variables (Sharma, 2017). This study examines the correlation between leadership behavior and instructor's job satisfaction at AMU.

\subsection{Problem Statement}

Teachers are the most important element of the educational system (Ayalew, 2009). Thus, one of the most important objectives of an educational organization is making the teachers satisfied and fulfilled. Instructional leaders are expected to provide teachers with direction and psychological satisfaction to achieve school goals and objectives (Anyango, 2015). However, the most common weakness among higher education leaders in Ethiopia is their inability to satisfy employees (Aytaged, 2016).

In the literature, there are a number of studies (e.g. Ali \& Dahie, 2015; Thomas, 2014) have been conducted to investigate the nexus between principals' leadership styles and teachers' job satisfaction and found positive link between them. Nevertheless, many of these studies were conducted abroad and focused on principals' leadership style and teachers' job satisfaction at primary and secondary school level.

In Ethiopia, a considerable amount of studies have been conducted on principals' leadership styles and their effects on teachers' performance (e.g., Ayene, 2016); teachers' job satisfaction and commitment (e.g., Teferi, Bekalu \& Abebe,2016) at secondary and primary schools. Thus, little attention has been given to Ethiopian higher education leadership behavior and instructor's job satisfaction. This study is; therefore, intended to fill this research gaps in examining the link between leadership behavior and instructor's job satisfaction at AMU. The study seeks to answer the following three basic research questions. 


\subsection{Basic Research Questions}

1. What is the relationship between leadership behavior and instructor's job satisfaction?

2. Which dimensions of leadership behavior is highly correlated with instructor's job satisfaction?

3. To what extent do leadership behavior affects instructor's job satisfaction?

\subsection{Objectives of the Study}

The main purpose of this study is to examine the nexus between leadership behavior and instructor's job satisfaction and the specific objectives are to address the basic research questions that included in the study.

\section{RESEARCH DESIGN AND METHODOLOGY}

\subsection{Research Design}

In this study, the quantitative correlational design was employed to examine the link between leadership behavior and instructor's job satisfaction as suggested by Gay \&Mills (2012).

\subsection{Population and Sampling Techniques}

In the study, purposive and simple random sampling techniques were used. Among five colleges, two institutes and three schools of Arba Minch University, I purposefully selected two colleges and two schools, namely, College of Social Sciences and Humanities and Business and Economics, School of Pedagogical and Behavioral Sciences and Law as thought of Creswell (2012). Accordingly, from the total of 287 local instructors in the sampled colleges and schools, 167 instructors consisting of 149 male and 18 female were selected via simple random sampling technique at confidence interval of $95 \%$ according to the Yamane's (1967) formula: $\mathrm{n}=\frac{\mathrm{N}}{\left[1+N(e)^{2}\right]}$ where, $\mathrm{n}=$ sample size, $\mathrm{N}=$ total population, $\mathrm{e}=$ level of precision. Hence, $\mathrm{n}=\frac{287}{\left[1+287(0.05)^{2}\right]}=167$. Then, proportionate stratified random sampling technique was employed to take representative sample instructors from each department and sex.

\subsection{Data Gathering Instruments}

In the study, two sets of standardized questionnaire were adapted to survey leadership behavior and instructor's job satisfaction. The Leadership Behavior Description Questionnaire (LBDQ)-Form XII self (1962), developed by staff members of the Ohio State Leadership Studies consisting of one hundred (100) items was used to survey leadership behavior. On the other hand, forty five (45) items of Academic Job Satisfaction Questionnaire (AJSQ) designed by Al-Rubaish et al. (2014) was employed to assess instructor's job satisfaction. The response options for both LBDQ -Form XII self (1962) was gauged in a five point Likert scale that ranging from 5= always to $1=$ never. While AJSQ's response options were designed by using 5 points Likert scales ranging from $5=$ strongly agree to $1=$ strongly disagree.

Before formal dissemination of the questionnaire, the instrument's reliability and validity was checked. To check the face validity of the questionnaire, I invited two psychology department staff members from Wolaita Sodo University who believed have ample experience in Educational Measurement and Evaluation. They reviewed the face validity of the questionnaire separately and jointly and reported the questionnaire as valid. Moreover, to check whether the questionnaire is reliable, I conducted pilot study on forty three (43) non-sampled teachers at Arba Minch Institute of Technology (AMIT). Then, the reliability of the twelve domains of the LBDQ and eight domains of the AJSQ including total reliability indices were computed at Cronbach's alpha level 0.5. The reliability results of LBDQ and AJSQ were judged according to George \& Mallery (2003) rules of digit: $>0.90=$ Excellent, $0.80-0.89=$ Good, $0.70-0.79=$ Acceptable, $0.60-0.69=$ Questionable, $0.50-0.59=$ Poor,$<0.50=$ Unacceptable. The following table summarizes the reliability results of the twelve domains of the LBDQ and eight domains of AJSQ. 
Table 2.3.1: Reliability Results of Leadership Behavior Description Questionnaire (N=43)

\begin{tabular}{llll}
\hline Variables & N0. of Items & Deleted Items & Cronbach's \\
& & Alpha Result & \\
\hline Representation & 5 & None & 0.858 \\
Reconciliation & 5 & None & 0.755 \\
Tolerance of Uncertainty & 10 & None & 0.774 \\
Persuasion & 10 & None & 0.917 \\
Initiation of Structure & 10 & None & 0.941 \\
Tolerance and Freedom & 10 & None & 0.894 \\
Role Assumption & 10 & None & 0.775 \\
Consideration & 10 & None & 0.807 \\
Production Emphasis & 10 & None & 0.868 \\
Predictive Accuracy & 5 & None & 0.873 \\
Integration & 5 & None & $0 . .902$ \\
Superior Orientation & 10 & & 0.874 \\
\hline Total Alph Result & & & 0.968
\end{tabular}

Total Alpha Result $\quad 100 \quad-0.968$

Note: Cronbach's alpha result of twelve leadership behavior variables

The above table 2.3.1 shows Cronbach's alpha result of twelve LBDQ constructs. As it can be seen from the table, all twelve LBDQ variables and total alpha result reveals acceptable reliability according to George \& Mallery (2003)

Table 2.3.2: Reliability Results of Academic Job Satisfaction Questionnaire (AJSQ) (N=43)

\begin{tabular}{lccc}
\hline Variables & N0. of Items & Deleted Items & \multicolumn{2}{c}{$\begin{array}{c}\text { Cronbach's } \\
\text { Alpha Result }\end{array}$} \\
\hline Authority & & \multicolumn{2}{c}{0.832} \\
Supervision & 9 & None & 0.919 \\
Policies and Facilities & 5 & None & 0.747 \\
Work itself & 9 & None & 0.737 \\
Interpersonal Relationships & 5 & None & 0.913 \\
Commitment & 5 & None & 0.903 \\
Salary & 4 & None & 0.782 \\
Workload & 4 & None & 0.732 \\
\hline Total Alpha Result & 4 & & 0.915 \\
\hline
\end{tabular}

Note: Cronbach's alpha result of eight instructor's job satisfaction variables

According to above table 2.3.2 eight constructs of AJSQ including total alpha result shows acceptable reliability like LBDQ.

\subsection{Data Collection Procedure}

Permission to conduct the data was sought from the Dean of purposefully selected colleges and schools of Arba Minch University. Before administering tools for data collection, the study target groups were introduced about the purpose of the study and their informed consents were secured. Consequently, questionnaires were administered to randomly selected instructors in their offices and collected by me and additional facilitators of the study.

\subsection{Data Analysis Method}

The data was analyzed quantitatively using SPSS v.20. Both descriptive and inferential statistics was employed. Descriptive statistics such as frequency and percentage was used to describe respondents' demographics. On the other hand, Pearson's correlation coefficient (r) was employed to examine the link between overall leadership behavior and instructor's job satisfaction and to identify leadership variables that highly correlated with instructor's job satisfaction. The strength and direction of correlation coefficient or (r) value was judged according to Gay's \& Mills's (2012) range: between +0.35 and $-0.35=$ weak or none, between +0.35 and +0.65 or between -0.35 and $0.65=$ moderate, between +0.65 and +1.00 or between -1.00 and $-0.65=$ strong. Finally, simple linear regression analysis was employed to predict the relation between leadership behavior and instructor's job satisfaction.

\section{ANALYSIS AND DISCUSSION OF RESULTS}

\subsection{Respondents' Demographics}

In the first part of questionnaire, the respondents were asked about their general background information. The following Table 3.1.1a \& 3.1.1b on page $7 \& 8$ indicates the response obtained from the respondents. 
Table 3.1.1a Respondents' demographic characteristics by sex, age and work experience $(\mathrm{N}=167)$

\begin{tabular}{llllll}
\hline Demographic & Category & $(\mathrm{F})$ & $(\%)$ & Valid (\%) & Cumulative (\%) \\
\hline Sex & Male & 149 & 89.2 & 89.3 & 89.3 \\
& Female & 18 & 10.7 & 10.7 & 100 \\
& Total & 167 & 99.9 & 100 & \\
\hline Age & $25 \&$ below & - & - & - & - \\
& $26-30$ & 59 & 35.3 & 35.4 & 35.4 \\
& $31-35$ & 93 & 55.6 & 55.7 & 91.1 \\
& $36-40$ & 15 & 8.9 & 8.9 & 8.9 \\
& $41 \&$ above & & & & \\
\hline Work experience & Total & 167 & 99.8 & 100 & - \\
& $1-5$ years & - & - & - & 32.9 \\
& $6-10$ years & 55 & 32.9 & 32.9 & 62.8 \\
& $11-15$ years & 50 & 29.9 & 29.9 & 89.3 \\
& $16-20$ years & 42 & 25.1 & 25.3 & 37.2 \\
& $21-25$ years & 20 & 11.9 & 11.9 & - \\
& $26-30$ years & - & - & - & - \\
\hline
\end{tabular}

The result of the above table 3.1.1a presents the demographic characteristics of respondents by sex, age and work experience. There were $149(89.2 \%)$ male respondents and the rest $18(10.7 \%)$ were female participants. Concerning age composition, majority of them were in between 31-35 years old 93 (55.6\%) followed by 26-30 years $59(35.3 \%)$ and few of them were in between $36-40$ years old $15(8.9 \%)$. This finding reveals that many study participants were adults and matured enough to fill the questionnaire. With regard to study participants' work experience, many respondents were served 6-10 years 55 (32.9\%), 11-15 years 50 (29.9\%), and 16-20 years 42 $(25.1 \%)$ and few of them were served $21-25$ years $20(11.9 \%)$. This indicates that the study subjects have good work experiences to fill the questionnaire based on their past work experience.

Table 3.1.1b Respondents' demographic characteristics by educational background, academic rank and current work positions $(\mathrm{N}=167)$

\begin{tabular}{|c|c|c|c|c|c|}
\hline \multirow{7}{*}{$\begin{array}{l}\text { Demographic } \\
\text { Educational } \\
\text { Background }\end{array}$} & Category & $(\mathrm{F})$ & $(\%)$ & Valid (\%) & Cumulative (\%) \\
\hline & B.A/B.Sc/ B.Ed Degree & - & - & - & - \\
\hline & M.A/M.Sc./M.Ed Degree & & & & \\
\hline & PhD Degree & 159 & 95.2 & 95.3 & 95.3 \\
\hline & Other & & & & \\
\hline & & 8 & 4.7 & 4.7 & 100 \\
\hline & Total & 187 & 99.9 & 100.0 & \\
\hline \multirow[t]{7}{*}{ Academic Rank } & Assistant Lecturer & - & - & - & - \\
\hline & Lecturer & 159 & 95.2 & 95.3 & 95.7 \\
\hline & Assistant Professor & 8 & 4.7 & 4.7 & 100 \\
\hline & Associate Professor & - & - & - & - \\
\hline & Professor & - & - & - & - \\
\hline & Other & & & & \\
\hline & Total & 187 & 98.9 & 100.0 & \\
\hline \multirow{3}{*}{$\begin{array}{l}\text { Current } \\
\text { Positions }\end{array}$} & As a teacher & 167 & 100 & 100 & 100 \\
\hline & Other & - & - & - & - \\
\hline & Total & 167 & 100 & 100.0 & \\
\hline
\end{tabular}

Note: IQE=Institutional Quality Enhancement, $P G=$ Postgraduate

The results from the above table $3.1 .1 \mathrm{~b}$ show the respondents' demographics by educational background, academic rank and current work position. From the total of one hundred sixty seven (167) respondents, 159 (95.2 \%) were M.A holders and the remaining few $8(4.7 \%)$ were PhD holders. Hence, majority of them $159(95.2 \%)$ were lecturers and few of them $8(4.7 \%)$ were assistant professors. Concerning the respondents' current work position, all of them $167(100 \%)$ were instructors. This information reveals that the respondents have good educational background, academic rank and work position to respond the administered questionnaire in a proper manner.

\subsection{Correlation Between Overall Leadership Behavior and Job Satisfaction}

This part is intended to answer the first research question that describes the major purpose of this study. The following table summarizes correlation coefficient ( $r$ ) value of overall leadership behavior and instructor's job 
satisfaction.

Table 3.2.1: Correlation Between Overall Leadership Behavior and Job Satisfaction ( $\mathrm{N}=167)$

\begin{tabular}{ll|l|l}
\hline & & Overall Leadership Behavior & Overall Job Satisfaction \\
\hline Leadership & Pearson Correlation & 1 & $.761^{*}$ \\
Behavior & Sig. (2-tailed) & & .049 \\
& $\mathrm{~N}$ & 167 & 167 \\
Job & Pearson Correlation & & 1 \\
Satisfaction & Sig. (2-tailed) & .049 & \\
& $\mathrm{~N}$ & 167 & 167 \\
\hline
\end{tabular}

Note: Correlation is significant at $p<0.05(2$-tailed)

The above table 3.2.1 shows the correlation between an overall leadership behavior and instructor's job satisfaction. According to the above table, there is statistically significant, strong and positive correlation between leadership behavior and instructor's job satisfaction $(\mathrm{r}=.761, \mathrm{p}<.049)$. This finding is consistent with many other researchers' findings, for instance, Ali \& Dahie (2015) and Thomas (2014).

\subsection{Correlation Between Variables of Leadership Behavior and Overall Job Satisfaction}

The intention of this part is to answer the second research question. The following table on page 10 shows the correlation between variables of leadership behavior and overall job satisfaction.

Table 3.3.1 Correlation Between Facets of Leadership Behavior and Overall Job Satisfaction (N=167)

\begin{tabular}{|c|c|c|c|c|c|}
\hline \multirow[t]{2}{*}{ Variables } & & $\begin{array}{l}\text { Overall Job } \\
\text { Satisfaction }\end{array}$ & Variables & & $\begin{array}{l}\text { Overall } \\
\text { Job Satisf. }\end{array}$ \\
\hline & Representation & & & Role Assum. & \\
\hline \multirow[t]{2}{*}{$\begin{array}{l}\text { Pearson Correlation } \\
\text { Sig. (2-tailed) } \\
\text { N }\end{array}$} & $\begin{array}{l}1 \\
167 \\
\end{array}$ & $\begin{array}{l}.762^{*} \\
.009 \\
167\end{array}$ & $\begin{array}{l}\text { Role } \\
\text { Assumption }\end{array}$ & $\begin{array}{l}\text { Pearson Corr. } \\
\text { Sig. (2-tailed) } \\
\text { N }\end{array}$ & $\begin{array}{l}.635^{*} \\
.023 \\
167 \\
\end{array}$ \\
\hline & $\begin{array}{l}\text { Demand } \\
\text { Reconciliation }\end{array}$ & & & Consideration & \\
\hline \multirow[t]{2}{*}{$\begin{array}{ll}\text { Demand Reconciliation } & \text { Pearson Correlation } \\
& \text { Sig. (2-tailed) } \\
& \mathrm{N} \\
\end{array}$} & $\begin{array}{l}1 \\
167\end{array}$ & $\begin{array}{l}.951^{*} \\
.000 \\
167\end{array}$ & Consideration & $\begin{array}{l}\text { Pearson Corr. } \\
\text { Sig.(2-tailed) } \\
\text { N }\end{array}$ & $\begin{array}{l}.958^{*} \\
.000 \\
167\end{array}$ \\
\hline & $\begin{array}{l}\text { Tolerance } \\
\text { of Uncertaint } \\
\mathrm{y}\end{array}$ & & & $\begin{array}{l}\text { Production } \\
\text { Emphasis }\end{array}$ & \\
\hline \multirow[t]{2}{*}{$\begin{array}{ll}\text { Tolerance of Uncertainty } & \text { Pearson Correlation } \\
& \text { Sig. (2-tailed) } \\
& \mathrm{N} \\
\end{array}$} & $\begin{array}{l}1 \\
167 \\
\end{array}$ & $\begin{array}{l}.696^{*} \\
.000 \\
167 \\
\end{array}$ & $\begin{array}{l}\text { Production } \\
\text { Emphasis }\end{array}$ & $\begin{array}{l}\text { Pearson Corr. } \\
\text { Sig.(2-tailed) } \\
\text { N }\end{array}$ & $\begin{array}{l}.760^{*} \\
.006 \\
167 \\
\end{array}$ \\
\hline & Persuasion & & & $\begin{array}{l}\text { Predictive } \\
\text { Accuracy }\end{array}$ & \\
\hline \multirow[t]{2}{*}{ Persuasion } & $\begin{array}{l}1 \\
167 \\
\end{array}$ & $\begin{array}{l}.698^{*} \\
.001 \\
167 \\
\end{array}$ & $\begin{array}{l}\text { Predictive } \\
\text { Accuracy }\end{array}$ & $\begin{array}{l}\text { Pearson Corr. } \\
\text { Sig.(2-tailed) } \\
\text { N }\end{array}$ & $\begin{array}{l}.871^{*} \\
.030 \\
167 \\
\end{array}$ \\
\hline & Initiation of St. & & & Integration & \\
\hline \multirow[t]{2}{*}{ Initiation of Structure } & $\begin{array}{l}1 \\
167 \\
\end{array}$ & $\begin{array}{l}.582^{*} \\
.006 \\
167 \\
\end{array}$ & Integration & $\begin{array}{l}\text { Pearson Corr. } \\
\text { Sig.(2-tailed) } \\
\text { N }\end{array}$ & $\begin{array}{l}.870^{*} \\
.029 \\
167 \\
\end{array}$ \\
\hline & $\begin{array}{l}\text { Tolerance and } \\
\text { Freedom }\end{array}$ & & & $\begin{array}{l}\text { Superior } \\
\text { Orientation } \\
\end{array}$ & \\
\hline $\begin{array}{l}\text { Pearson Correlation } \\
\text { Sig. (2-tailed) } \\
\mathrm{N}\end{array}$ & $\begin{array}{l}1 \\
167 \\
\end{array}$ & $\begin{array}{l}.634^{*} \\
.023 \\
167 \\
\end{array}$ & $\begin{array}{l}\text { Superior } \\
\text { Orientation }\end{array}$ & $\begin{array}{l}\text { Pearson Corr. } \\
\text { Sig.(2-tailed) } \\
\mathrm{N}\end{array}$ & $\begin{array}{l}.667^{*} \\
.000 \\
167 \\
\end{array}$ \\
\hline
\end{tabular}

Note: Correlation is significant at $* 0.05$ (2-tailed)

The above table 3.3.1 depicts the correlation between dimensions of leadership behaviors and instructor's job satisfaction. As we can see from the table, all leadership behavior variables have a positive correlation with job satisfaction. Nevertheless, representation $(\mathrm{r}=.762, \mathrm{p}<.009)$, demand reconciliation $(\mathrm{r}=.951, \mathrm{p}<.000)$, tolerance of uncertainty $(\mathrm{r}=.696, \mathrm{p}<.000)$, persuasiveness $(\mathrm{r}=.698, \mathrm{p}<.001)$, consideration $(\mathrm{r}=.958, \mathrm{p}<.000)$, production emphasis $(\mathrm{r}=.760, \mathrm{p}<.006)$, predictive accuracy $(\mathrm{r}=.871, \mathrm{p}<.030)$, integration $(\mathrm{r}=.870, \mathrm{p}<.029)$ and superior orientation $(\mathrm{r}=.667, \mathrm{p}<.000)$ have strong and positive correlation with instructor's job satisfaction than other variables. On the other hand, initiation of structure $(r=.582, \mathrm{p}<.006)$, tolerance and freedom $(\mathrm{r}=.634, \mathrm{p}<.023)$ and role assumption $(\mathrm{r}=.635, \mathrm{p}<.023)$ were moderately associated with job satisfaction. The results suggest that if leaders do practice different leadership behaviors then the job satisfaction of teachers will increase, because leadership dimensions have strong, moderate and positive relationship with job satisfaction of teachers. 


\subsection{Simple Linear Regression Analysis}

In this part, simple linear regression analysis was computed to answer the third basic research question. The following information shows the result of simple linear regression analysis.

Table 3.4.1 Model Summary of Leadership Behavior and Job Satisfaction

\begin{tabular}{l|l|l|l|l}
\hline Model & R & R Square & Adjusted R Square & Std. Error of the Estimate \\
\hline 1 & $.761^{\mathrm{a}}$ & .580 & .159 & .14824 \\
\hline
\end{tabular}

a. Predictors: (Constant), Leadership Behavior

The model summary in Table 3.4.1 shows that the coefficient of determination $\left(R^{2}\right)$ was 0.580 . This means that leadership behavior explained 58\% percent of the variations in instructor's job satisfaction. In other words, 42 percent of the variation in instructors' job satisfaction cannot be explained by leadership behavior. So, there must be other factors that are not incorporated in the model to explain job satisfaction of the instructor.

Table 3.4.2 ANOVA of Leadership Behavior and Job Satisfaction

\begin{tabular}{ll|l|l|l|l|l}
\hline \multicolumn{2}{c|}{ Model } & Sum of Squares & $\mathrm{df}$ & Mean Square & $\mathrm{F}$ & Sig. \\
\hline \multirow{3}{*}{1} & Regression & .030 & 1 & .030 & & \\
& Residual & .022 & 1 & .022 & 1.378 & $.049^{\mathrm{b}}$ \\
& Total & .052 & 2 & .022 & & \\
\hline
\end{tabular}

a. Dependent Variable: Job Satisfaction b. Predictors: (Constant), Leadership Behavior

The above table 3.4.2 shows the ANOVA of leadership behavior and job satisfaction. It is used to assess the statistical significance of the result. The analysis revealed that the $F$-value $=1.378$ and the $p=.049$. The model was therefore significant because $p<.05$. It was concluded that leadership behavior in the model had a significant relation with instructor's job satisfaction.

Table 3.4.3 Coefficients of Leadership Behavior and Job Satisfaction

\begin{tabular}{l|l|l|l|l|l}
\hline Model & \multicolumn{2}{|l|}{ Unstandardized Coefficients } & $\begin{array}{l}\text { Standardized } \\
\text { Coefficients }\end{array}$ & $\mathrm{t}$ & Sig. \\
\hline 1 & $\mathrm{~B}$ & Std. Error & Beta & & \\
\cline { 2 - 6 } (Constant) & 1.632 & .976 & & 1.673 & .043 \\
Leadership Behavior & $3.212 \mathrm{E}-008$ & .000 & .761 & 1.174 & .049 \\
\hline
\end{tabular}

a. Dependent Variable: Job Satisfaction

The above table 3.4.3 shows the coefficients of Leadership Behavior and Job Satisfaction. According to the table, the largest beta coefficient (.761) which is the independent variable (leadership behavior in this case) and this indicates leadership behavior makes the strongest unique contribution to the explaining dependent variable (job satisfaction).

\section{CONCLUSIONS AND IMPLICATIONS \\ 4.1 Conclusions}

Based on results and discussions of data, the following conclusions remarks made:

As the finding of the overall leadership behavior and job satisfaction showed that there is a positive link between leadership behavior and instructor's job satisfaction. Furthermore, among twelve dimensions of leadership behaviors, nine variables are strongly and positively correlated with job satisfaction and the remaining three variables are moderately associated with job satisfaction. On the other hand, the independent variable (leadership behavior) makes strong and unique contribution to explaining dependent variable (job satisfaction) as the findings from simple regression analysis indicate.

\subsection{Implications For AMU}

There is a statistically positive link between leadership behavior and instructor's job satisfaction according to the findings of this study indicates. Hence, through both formal and informal trainings, the university leaders should aware how their leadership behavior is correlated with instructor's job satisfaction and then they should adopt and practice different dimensions of leadership behavior to improve teacher's job satisfaction.

\subsection{Implications For Further Research}

This study was confined to the purposefully selected colleges and schools from Arba Minch University and the findings may not be generalizable to other Ethiopian public universities. Thus, further studies can focus on the link between leadership behavior and instructor's job satisfaction by taking a representative sample from Ethiopian Public Universities.

\section{ACKNOWLEDGEMENT}

I am grateful to Professor Ayalew Shibeshi, Department of Educational Planning and Management, Addis Ababa University, for sharing all his endeavors and scholastic stamina in teaching two postgraduate courses which laid 
foundation for this seminar research in leadership.

\section{REFERENCES}

Abbas, W. \& Asghar, I. (2010). The Role of Leadership in Organizational Change: Relating the Successful Organizational Change to Visionary and Innovative Leadership, Unpublished M.A Thesis in Industrial Engineering and Management, University of Gavle.

Ali, A. \& Dahie, A. (2015). Leadership Style and Teacher Job Satisfaction: Empirical Survey from Secondary Schools in Somalia, Research on Humanities and Social Sciences, Vol.5, No.8.

Al-Rubaish, A. (2011). Academic Job Satisfaction Questionnaire: Construction and Validation in Saudi Arabia, Journal of Family and Community Medicine, Vol. 18, Issue 1, pp. 1-7.

Anyango, C. (2015). Effects of Leadership Styles on Employee Performance at Boa Kenya Limited, Unpublished M.A Thesis in Human Resources Management, Open University Of Tanzania.

Ayalew Shibeshi. (2009). Secondary School Teacher Deployment in Ethiopia: Challenges and Policy Options for Redressing the Imbalances, Proceedings of the $16^{\text {th }}$ International Conference of Ethiopian Studies.

Ayene Tamrat. (2016). Principals' Leadership Styles and Their Effects on Teacher's Performance in the Tigray Region of Ethiopia, Unpublished PhD Dissertation in Education Management, University of South Africa.

Aytaged Sisay. (2016). A Call for a Leadership Style Change in Ethiopian Higher Education, the Ethiopian Journal of Education, Vol. XXXIV, No. 2.

Bakotić, D. (2016). Relationship Between Job Satisfaction and Organizational Performance, Economic ResearchEkonomska Istraživanja, Vol. 29, N0. 1, 118-130.

Belias, D. \& Koustelios, A. (2014). Leadership and Job Satisfaction: A Review, European Scientific Journal, Vol.10, No.8.

Creswell, J. (2012). Educational Research: Planning, Conducting, and Evaluating Quantitative and Qualitative Research $\left(4^{\text {th }} \mathrm{ed}.\right)$, University of Nebraska-Lincoln.

Gay, L. \& Mills, G. (2012). Educational Research: Competencies for Analysis and Applications, $10^{\text {th }}$ edition, Pearson Education, Inc.

George, D. \& Mallery, P. (2003). SPSS for Windows step by step: A Simple Guide and Reference 11.0 update (4 $4^{\text {th }}$ ed.). Boston: Allyn \& Bacon.

Jabbar, A. \& Hussein, A. (2017). The Role of Leadership in Strategic Management, International Journal of Research - Granthaalayah, Vol.5, Issue, 5.

Leader Behavior Description Questionnaire - Form XII Self (1962) Originated by Staff Members of the Ohio State Leadership Studies and Revised by Bureau of Business Research.

Sharma, S. (2017). Job Satisfaction Amongst College Teachers In Malwa Region Of Punjab: A Comparative Study On The Basis Of Gender, International Conference on Recent Innovations in Science, Agriculture, Engineering and Management, India.

Teferi Getahun, Bekalu Ferede \& Abebe Hunde (2016). Teacher's Job Satisfaction and Its Relationship With Organizational Commitment in Ethiopian Primary Schools Focus on Primary Schools of Bonga Town, European Scientific Journal, Vol.12, No.13.

Thomas, S. (2014). The Effects of Principal Leadership Behavior on New Teacher's Overall Job Satisfaction, Unpublished Doctoral Dissertation, Walden University.

Yamane, T. (1967). Statistics: An Introductory Analysis (2 $2^{\text {nd }}$ ed.), New York: Harper and Row. 